\title{
22
}

\section{CEMENT DUST FROM KUNDA NORDIC CEMENT (KNC) FACTORY}

Andres Pirsalu

Entec AS

Estonia

\section{PRESENT SITUATION}

The Kunda cement factory is the main polluter in the town of Kunda and in the Lääne-Virumaa county. The main pollution from the factory is dust. During the renovation of the factory all dust control equipment will be either repaired or renewed.

The cost estimate of the investment program during 1993-1996 is 578 million Estonian kroons (EEK). The costs of all environmental investments during the four year renovation period is estimated to be approximately 125 MEEK (appr. $22 \%$ of the total investment sum).

The main dust emitters are rotary kilns. In 1994 the annual dust emission in to the air was 55233.9 tons, from that 1472.3 tons was cement dust. During the period of 1995-96 Kunda Nordic Cement Corp. has renovated and installed new effective electric precipitators to 2 rotary kilns. According to the 1997 prognosis these filters catch $45000 \mathrm{t}$ of clinker dust that present is being transported to the landfill as the dust lacks any field usage. The landfill is heavily over-burdened which in its turn leads to unnecessary extra costs. 


\section{EMISSION PROGNOSIS}

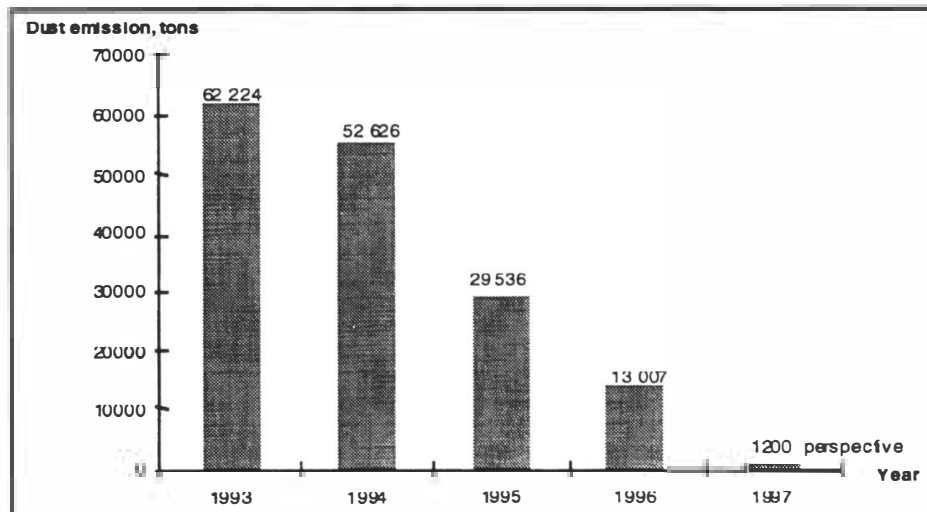

Fig. 1: Dust emission from kilns $1993-1997$

\section{EMISSIONS TO THE AIR}

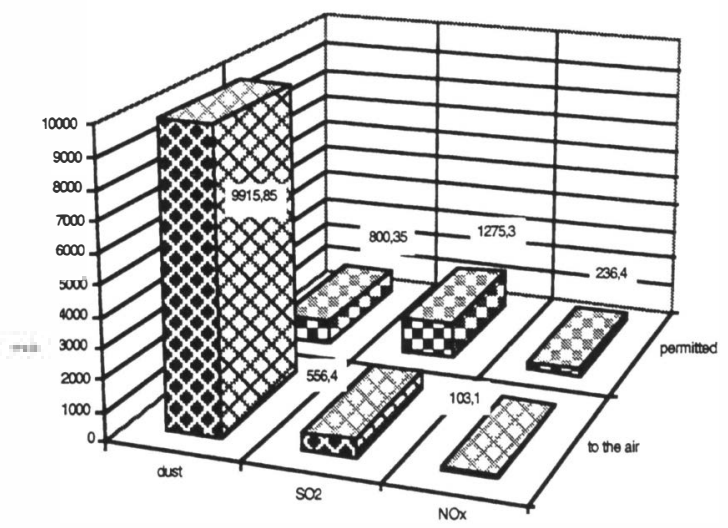

Fig. 2: Dust and gaseous emissions into the air in the first quarter of 1995

In the first quarter of the year $1995 \mathrm{KNC}$ paid $906327 \mathrm{EEK}$ pollution tax for emissions. $899828 \mathrm{EEK}$ for dust emission was paid, $16499 \mathrm{EEK}$ for gaseous emissions was paid. 


\section{AIR PERMIT}

Table 1: Permitted emissions

\begin{tabular}{|c|l|c|}
\hline Code of pollutant * & Pollutant and emitter & $\begin{array}{c}\text { Permitted emission } \\
\text { (Tons annually) }\end{array}$ \\
\hline 1401 & Non toxic dust & 1129 \\
& Kilns & 126 \\
& Oilshale mills \\
& Limestone quarry & 74 \\
\hline \multirow{2}{*}{1310} & Cement dust and fly ash & 38 \\
& Cement mills & 227 \\
& Coolers & 9 \\
\hline 2345 & Port & 5172 \\
\hline 2245 & $\mathrm{SO}_{2}$ Kilns & 959 \\
\hline 2426 & $\mathrm{NO}_{2}$ Kilns & 372 \\
\hline
\end{tabular}

* Codes of pollutants according to Estonian Pollutant Index

\section{WASTE PERMIT}

In January 1996 a new waste permit for the $\mathrm{KNC}$ was issued

Table 2: Wastes permitted to dump to the Kunda Landfill in 1966

\begin{tabular}{|l|c|c|c|}
\hline & Danger class & Code & $\begin{array}{c}\text { Permitted amounts } \\
\text { in tons annually }\end{array}$ \\
\hline Construction wastes & 5 & 21503 & 4,000 \\
\hline Wastes of mineral insulation & 4 & 21508 & 1 \\
\hline Materials & & & \\
\hline Asbetos and asbetos dust & 4 & 21510 & 1 \\
\hline Inert production wastes & 5 & 21705 & 5,000 \\
\hline Dust from cement kilns & 4 & 21799 & 40,000 \\
\hline Sediment from slurry basins & 4 & 21804 & 200 \\
\hline $\begin{array}{l}\text { Wastes of tiles containing chrome- } \\
\text { magnesium compounds }\end{array}$ & 3 & 31207 & 800 \\
\hline Tires of vehicles & 5 & 37502 & 1 \\
\hline Ground containing mineral oils & 3 & 34408 & 25 \\
\hline Total & & & $\mathbf{5 0 , 0 2 8}$ \\
\hline \hline
\end{tabular}

Code and danger class of wastes are given according to the Estonian Waste Index. 


\section{LANDFILL DEVELOPMENT}

As a result of the reconstruction of the cement factory the ahhual amount of cement dust from kilns will arise from 8000 - 11000 tons in 1995 to 46000 54000 tons in 1998. Together with oil-shale dust from the power plant ( 25000 tons) and building material waste with contaminated soil ( 37000 tons) the annual amount will be approximately 116000 tons of solid wastes.

Seepage water from the new landfill will be collected together with stormwater of the landfill area and after dilution it will be pumped into the channel collecting stormwater around the landfill site. Presumably the collected seepage water is with a high alkaline reaction and without organic components. If dilution will not prove adequate enough, neutralization should be used.

To prevent pollution due to contaminated water from the old landfill two alternatives have been compared: pumping it into the cement plant for incineration and pumping it into the municipal wastewater system. For incinerating and intermediate water tank (4-5 day storage) is necessary as well as an equipment to pump water into the raw material mills. Everything should be adjusted to meet the technological needs of water. The above said makes this alternative complicated and expensive. The other alternative is worked out according to the technical requirements issued by a company managing the sewage system of Kunda. According to this alternative the leakage water will be collected and pumped into the wastewater system of the town.

\section{USING OF DUST}

Due to the installation of the new effective electric precipitators certain changes have taken place in the chemical composition of the caught dust and the relative importance of plant nutrients in the dust has grown. Therefore the matter of possible usage of clinker dust as a lime fertilizer and a source of plant nutrients $(\mathrm{K}$, $\mathrm{Mg}, \mathrm{S}, \mathrm{P}$ ) has arisen again.

Agricultural scientists have come to the conclusion that in spite of the practice of using Ca-containing fertilizers in Estonia, without lime fertilizers the acid soils balance as to $\mathrm{Ca}$ is negative by $120 \mathrm{~kg} / \mathrm{t}$, such an amount corresponds to approximately $432 \mathrm{~kg}$ of clinker dust.

At present it is considered extremely necessary to start regular liming of agricultural soils, i.e. at least $30 \ldots 35000 \mathrm{ha}$...

Liming of acid soils as a process of soils chemical amelioration means a thorough change in the agro-chemical properties of soil, all this in order to improve its productivity.

Thanks to Estonian research work of international importance, followed by promotion, extensive liming of acid soils was carried out during 1950-1996. An area of 1839100 ha was limited. Liming of acid soils was particulary wide-spread during 1966-1989, the annual average limed agricultural area amounting to 63750 ha. 
As agricultural test results from 1950-1996 show the productivity of soil increased like this: 1 ton $\mathrm{CaCO}_{3}$ gave 290 food units bigger crops.

In the course of last 5 years the annual limed area has totally amounted only to 4150 ha, compared to the period of 1966-1989 the figure is 15 times lower. 